\title{
バブル経済崩壊後の市場縮小時代における造園業の 実態と課題
}

\author{
Present Situation and Problems of Landscape Construction Industry in the 'Market Reduction Era' \\ Following the Burst of Bubble Economy
}

\author{
田中 史郎 ${ }^{*}$ 齋藤 雪彦** 藤井英二郎** 鳥井 幸恵 ${ }^{* *}$ 近江屋一朗** \\ Shiro TANAKA Yukihiko SAITO Eijiro FUJII Yukie TORII Ichiro OUMIYA
}

\begin{abstract}
The purpose of this study is to clarify the present situation and problems of landscape construction industry in this ' market reduction era' following the burst of bubble economy from the aspect of its sales. We sent out questionnaires to 600 landscape construction enterprises. We also obtained their business evaluation data from the web site of Construction Industry Information Center. By analyzing the above data, it turned out a third of the sales of landscape construction industry came from landscape construction itself, but the rest from businesses other than landscape construction. It also emerged that as the value of sales increased, the proportion of the sales obtained from businesses other than landscape construction increased. However, it seems that few enterprises try to expand businesses other than landscape construction. Landscape construction industry should develop new businesses to cope with the needs in the modern society.
\end{abstract}

Keywords: landscape construction industry, value of sales, business evaluation, questionnaire キーワード : 造園業, 売上高, 経営事項審査, アンケート調査

1.はじめに

バブル経済崩壊後，造園業市場は縮小している。造園工事業の 完成工事高が 1991 年の 10,259 億円から 2006 年度の 5,795 億円 まで減少したことからもこのような状況をうかがうことができ

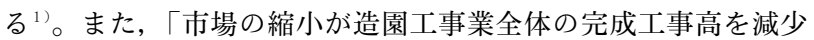
させ, 営業利益がマイナスまでになった。」とするマクロな分析が報 告されているが2), 造園工事業全体の完成工事高以外の売上高がど のようになったかまでは解明されていない。造園業を研究の対象 とする場合, 造園業企業の全売上高の実態を解明する必要がある。

本研究は，市場の縮小に対応した結果，個々の企業がどのよう な状態になったか，また今度どのようにしようとしているか，そ の実態を企業活動の基をなし企業行動が反映される売上高を主な 視点として分析し，そこに予見される課題を明らかにすることを 目的とする。

また，本研究は造園産業論と言うべき範疇に含まれるもので, 進士が「高い理想と科学的で具体的なデー夕に基づき，しかも関 係者, 関係機関をあげて, 本格的に「造園産業論」の構築に取り 組まなければならない。また，そうした産業論を確立できるよう な造園産業界の研究体勢を整えることの緊急度も高いように思わ れる。」呈) と述へているとおり造園学界においては新たな研究分 野としての展開が求められている。また, その際造園業市場の縮 小と言う時代背景を踏まえる必要がある。

なお, 本研究を含めた一連の研究の最終的ねらいは, 社会環境 の変化に対応した都市および地方（地域）の良好な空間の実現で あり，良好な空間の実現者である造園業の健全な発展である。す なわち, 造園業にかかわる「産業論」としての深化が良好な空間 の実現には不可欠なのであるという考えが基となっている。

\section{2. 研究方法}

（1）個々の企業情報の入手

個々の企業情報は，インターネット上で公表されている経営事
表－ 1 アンケート調査の概要

\begin{tabular}{|l|l|l|l|}
\hline アンケート実施期間 & \multicolumn{2}{|l|}{2007 年7月28日から8月20日まで } \\
\hline 配布数 & 600 社 & 回答数 & 136 社(回答率22.7\%) \\
\hline 調査内容 & 基本属性、事業の実態と今後の意向、 & 従業者の実態、その他 & （計45問) \\
\hline
\end{tabular}

項審査デー夕 ${ }^{4)}$ および造園業企業を対象に郵送調査法によるアン ケート調査から入手した。

(1)経営事項審査デー夕

経営事項審査デー夕は，(社)日本造園建設業協会 ${ }^{5}$ お よび(社)日本 造園組合連合会 ${ }^{6)}$ の 2007 年度会員 5,905 社の全企業について, (財)建設業情報管理センターのホームページにアクセスし， 2,865 社の経営事項審査デー夕を入手した（情報入手期間：2008 年 2 月から 2008 年 6 月まで)。

(2)アンケート調査

(社)日本造園建設業協会および社)日本造園組合連合会の会員でか つ経営事項審査を受けている企業から地域および企業規模に偏り のないように 600 社を選び表一 1 のとおりの郵送によるアンケー 卜調查を実施した。

\section{(2) 分析の手法}

企業行動は企業規模により異なるものと考えられるため, 本研 究における企業規模の指標を市場の縮小が最も反映したと考えら れる売上高とし, 企業規模別に売上高の構成, 経営者の意向およ び相互の関係を分析した。また, 経営事項審査データで得られな い情報をアンケート調查から得たため, 個々の分析テーマごとに 経営事項審査データとアンケート調査結果を交えて分析した。

(3) 本研究で対象とした企業の位置付け

造園業企業を造園工事業の建設業許可 ${ }^{7)}$ 取得等により図-1の とおり区分することができる。

本研究で対象とした企業は「経営事項審査を受けている企業」

*(森)中村製作所 ${ }^{* *}$ 千葉大学大学院園芸学研究科 
であり, 造園工事を行うが民間工事のみを行うため経営事項審査 を受けていない企業, また 1 物件 500 万円未満の造園工事のみを 行う規模の小さな企業は含まれていない。さらに, (社日本造園建 設業協会, (社)日本造園組合連合会の会員企業であることから経営 事項審査を受けていても両団体に加盟していない，造園工事が主 要な業務でないと考えられる企業は含まれていない。

\section{3. 結果と考察}

\section{(1) 売上高の全体像}

造園業企業の売上高を図-2 のとおりの事業に区分することが できる。

経営事項審査データから図ー 2 の事業ごとの売上高構成比は, 造園工事高 32.5\%（119 百万円／社)，造園工事以外の工事高 21.3\% (78 百万円 / 社), 建設工事以外の売上高 46.3\%（169 百 万円／社）となった。

企業規模区分について, 入手した経営事項審査データ 2,865 社 を売上高 1 億円未満, それ以上を 10 億円単位で区分し，その区 分に属する企業の売上高総額と企業数を示したのが図ー 3 である。 企業数は売上高 1 億円未満の企業が 1,694 社 (59.1\%), 売上高 1 億円以上 10 億円未満の企業は 1,067 社 (37.2\%), 売上高 10 億 円以上の企業は 104 社（3.6\%）となった。企業数は，売上高 1 億円未満の企業と 1 億円以上 10 億円未満の企業に集中した。一 方，売上高総額は売上高 1 億円未満の企業は 761 億円（7.3\%), 売上高 1 億円以上 10 億円未満の企業は 2,874 億円 (27.4\%), 売 上高 10 億円以上の企業は 6,846 億円（65.3\%）となった。以上 から全企業数の $96 \%$ 以上が属している売上高 1 億円未満と 1 億 円以上 10 億円未満, 全売上高総額の $65 \%$ 以上を占める売上高 10 億円以上を企業規模の大区分とした。

この企業規模大区分内に扔ける売上高構成比をみると（図 -4 , 5,6 ), 売上高 6 千万円未満の企業では, 造園工事高の割合が 約 $60 \%$, 造園工事以外の工事高の割合が約 10\%, 建設工事以外 の売上高の割合が約 $30 \%$ となった。売上高 6 千万円以上 1 億円 未満の企業では, 造園工事高の割合が $60 \%$ 超え, 全工事高の

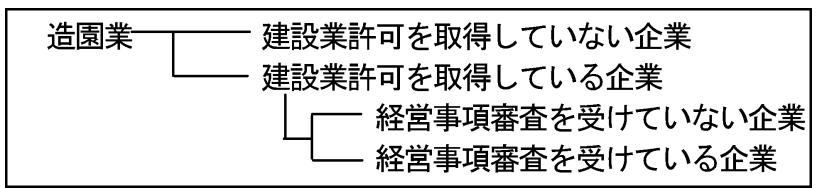

図-1 造園工事業の許可取得等による分類

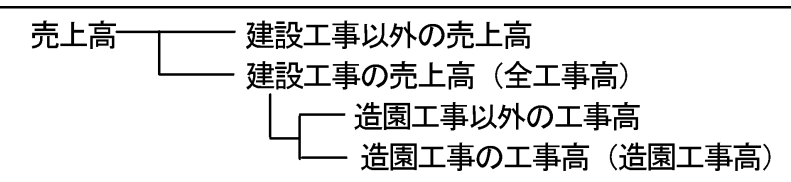

図-2 売上高の事業区分

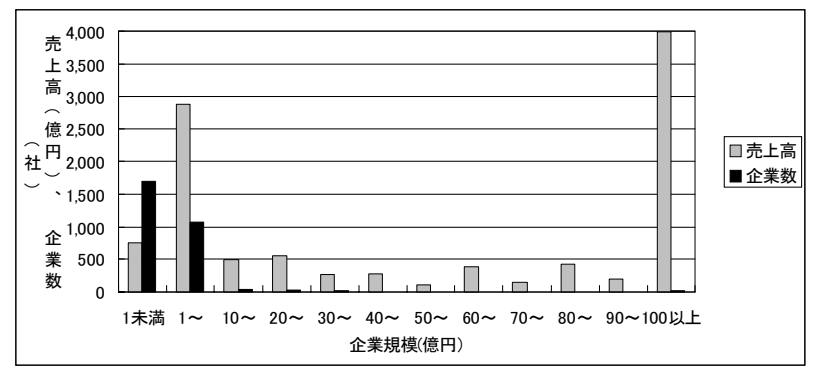

図-3 企業数と売上高（経営事項審査デ"-夕）
割合が 7 割を超えた。売上高 1 億円以上 6 億円未満の企業では, 造園工事以外の工事高の割合が増加し，全工事高の割合が $80 \%$ 前後となった。売上高 6 億円以上 10 億円未満の企業では, 建設 工事以外の売上高の割合が増加し，その結果，造園工事高自体は 増加しているものの造園工事高の割合が減少した。売上高 10 億 円以上の企業では，企業規模におけるまとまりがみられないもの の, 全体的には造園工事高の割合が減少し, 造園工事以外の工事 高と建設工事以外の売上高の割合が増加した。

企業規模は売上高を指標に設定したため，企業規模が大きくな るに従い売上高の中心となる造園工事高が大きくなるのは当然で あるが，売上高 6 千万円以上 1 億円未満の企業では造園工事高の 割合が増加し， 1 億円以上 6 億円未満の企業では造園工事以外の 工事高が増加し， 6 億円以上 10 億円未満の企業では建設工事以 外の売上高が増加した。売上高 10 億円以上の企業では造園工事 以外の工事高と建設工事以外の売上高の割合が増加し, 造園工事 高の割合が減少した。市場が縮小した現状においては，造園工事 以外の工事高, 建設工事以外の売上高が企業全体の売上高の構成 上，重要な意味を持っていると考えられる。

以上のように売上高構成比のまとまりをみせた売上高 6 千万円 未満, 6 千万円以上 1 億円未満, 1 億円以上 6 億円未満, 6 億円 以上 10 億円未満, 10 億円以上の 5 区分を企業規模の中区分とし て, 造園工事高, 造園工事高以外の工事高, 建設工事以外の売上 高に分けて分析を行った。

\section{（2）造園工事高}

アンケート調査結果からどのような規模の造園工事を行ってい るかを工事単価別に工事件数をみたのが図ー7である。全体では, 工事物件の $50.5 \%$ が 50 万円未満の工事となった。企業規模別に

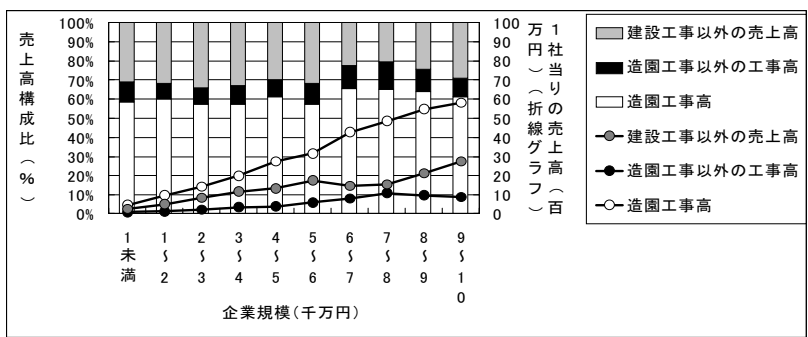

図-4 売上高の構成（売上高：1 億円未満）（経営事項審査デ -タ）

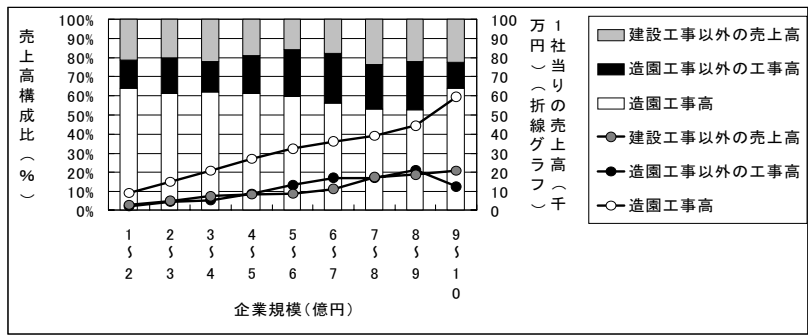

図－5 売上高の構成（売上高：1～10 億円）（経営事項審査テ" -g）

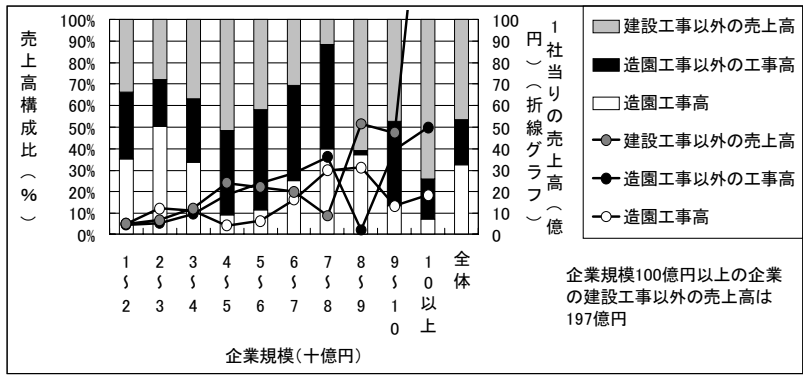

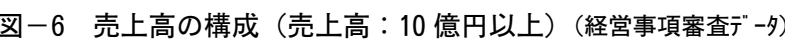


みると売上高 6 千万円未満の企業は工事物件の $69.6 \%$ が 50 万円 未満の工事であった。売上高 6 千万円以上 1 億円未満の企業では 50 万円以上 100 万円未満の工事が $26.0 \% ， 100$ 万円以上 200 万 円未満の工事が $12.4 \%$ と規模の大きな工事を受注した。売上高 1 億円以上 6 億円未満の企業では売上高 6 千万円以上 1 億円未満の 企業よりも規模の小さな工事を受注したが，工事物件が 2.5 倍の 126 件／社となった。売上高 6 億円以上 10 億円未満の企業では 200〜500 万円の工事を $8.7 \%$ 受注するようになった。売上高 10 億円以上の企業は 1000 万円以上の工事を $9.4 \%$ 受注するように なったが, 50 万円未満の工事も $39.4 \%$ 受注した。企業規模が大 きくなるに従い, 主要工事が大規模工事に移行するのではなく規 模の大きな工事が加わることが特徵的である。また， 1 社当りの 工事件数は企業規模が大きくなるに従い増加し, 特に売上高 1 億 円以上の企業においては企業規模が大きくなるに従い工事件数が 急激に増加し, 売上高 10 億円以上の企業では 1 社当り年間 520 件の工事を行った。アンケート調査結果から工事規模別の外注率 を示したのが図－8 である。工事物件が増加する売上高 1 億円以 上の企業では, 工事件数と同様に企業規模が大きくなるに従い外 注率も高くなったことから, 大量の工事物件に対しては, 自社の 技術者, 現場労働者だけで工事を行うのではなく, 下請造園業企 業への外注等のネットワークで業務が行われていると考えられる。

次に，造園工事高を施主が公共か，民間かで分けたのが図－9 である。全体では民間工事が造園工事高の $71.3 \%$ 占めた。企 業規模別にみると, 売上高 10 億円未満の企業においては企業規 模が大きくなるに従い公共工事高が $36.3 \%$ から $64.0 \%$ まで増加 したが, 売上高 10 億円以上の企業は公共工事高が $21.9 \%$ と少な くなった。

また, 造園工事高を元請, 下請工事に分けたのが図ー10であ る。全体では, 元請, 下請工事高がほぼ均衡した。企業規模別に みると概ね企業規模が大きくなるに従い元請工事高の割合が低下 する傾向がみられ, 売上高 10 億円以上の企業では元請工事高の 割合が $49.2 \%$ と下請工事高を下回った。

さらに, (社)日本造園建設業協会および社)日本造園組合連合会で 会員企業が行っている造園工事についてヒアリング調査を行っ た ${ }^{8)}$ 。ヒアリング調查から企業規模別の売上高を構成する主な工 事内容をまとめると次のとおりになった。売上高 1 億円未満の企 業は地縁等から個人庭園の作庭, 地元地域の事業所等の外構工事

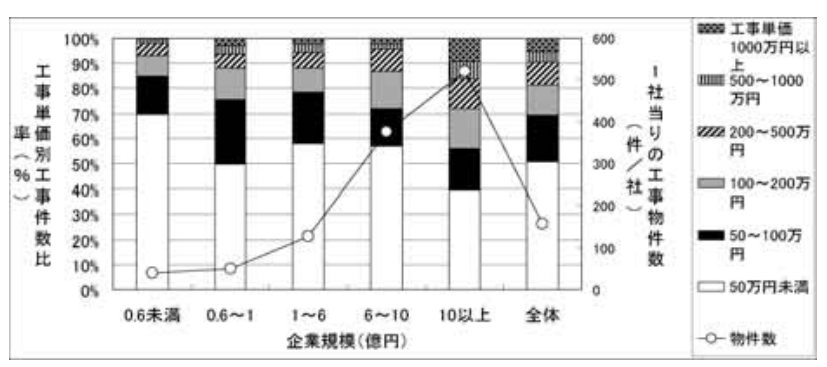

図-7 工事単価別物件数（アソケート調査）

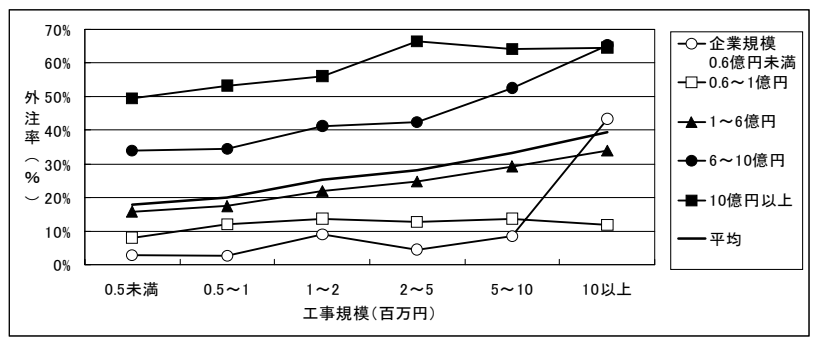

図－8 工事規模別平均外注率（アソケート調査）
を行っていた。加えて, 地方自治体（市町村）の地元中小企業保 護政策による小規模公共工事の受注, 中堅造園業企業（売上高 1 億円以上 10 億円未満）がゼネラルコントラクター（以下，ゼネ コン), ディベロッパー（ハウスビルダーを含む）から受注した 公共施設または工場, 商業施設, マンション, 戸建住宅等の外構 工事の下請を行っていた。売上高 1 億円以上 10 億円未満の企業 では, 市町村または都道府県が発注するより規模の大きな公共工 事, 前述のとおりのゼネコンからの下請工事およびディベロッパー からの元請工事を行った。売上高 10 億円以上の企業では大手ゼ ネコン，ディベロッパーの系列企業または信頼関係を結んだ企業 が多くみられ，ゼネコンからの都市再開発事業による複合商業施 設, 環境配慮型マンション等の外構工事, さらにディベロッパー が開発した住宅地の外構工事を行っていた。大型公共工事も行う が，その工事規模，工事物件数は減少していた。

以上のヒアリング調查結果からアンケート調査結果を考察する と, 売上高 1 億円未満の企業は地元の個人または事業所が発注す る民間工事を元請として受注する工事，売上高 1 億円以上 10 億 円未満の企業はゼネコンからの民間工事の下請および地方自治体 からの公共工事を元請として受注する工事, 売上高 10 億円以上 の企業は大手ゼネコンの民間下請工事，ディベロッパーからの民 間元請工事が売上高の大きな割合となっていると考えられる。

\section{(3) 造園工事以外の工事高}

\section{(i ) 工事高の構成}

建設業法では建設業を 28 業種と定め，工事を行うためにはそ れぞれの業種について大臣または知事の許可が必要としている。 本研究で用いた経営事項審査データの企業は全て造園工事業の建 設業許可を取得しているが, 造園工事業以外の建設業の許可取得 の実態と売上高に占める工事高の割合を示したのが表ー 2 である。

全体では, 1 社当り造園工事業以外に 2.68 業種取得していた。 また，これらの工事高は全売上高の $21.3 \%$ を占めた。企業規模 が大きくなるに従い取得業種数も増加し，10 億円以上の企業で は 1 社当り 6.28 業種の許可を取得していた。工事高も同様に企 業規模と共に増加し，10 億円以上の企業では工事高は 15.3 億円 ／社となった。しかし，全売上高に占める割合は売上高 10 億円 以上の企業が $23.3 \%$ と，売上高 6 億円以上 10 億円未満の企業の 24.1\%（1.7 億円／社）よりも低くなった。これは売上高 10 億円 以上の企業は後述する建設工事以外の売上高が大きいためである。

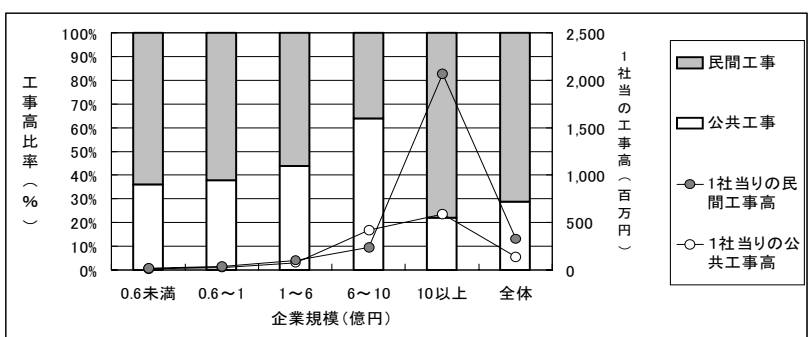

図－9 造園工事の公共・民間工事高比率（アソケート調査）

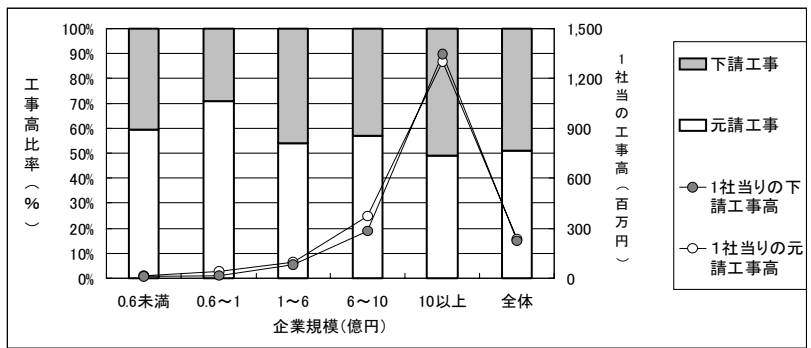

図－10 造園工事の元請・下請工事高比率（アソケート調査） 
表 $-2 \quad 1$ 社当りの建設業許可取得数と工事高の割合（経営事項審査 $\bar{\gamma}^{\prime}-$-タ）

\begin{tabular}{|c|c|c|c|c|c|c|}
\hline 企業規模 & $\begin{array}{r}\text { 6千万円 } \\
\text { 未満 } \\
\end{array}$ & $\begin{array}{l}6 \text { 千万円 } \\
\sim 1 \text { 億円 } \\
\end{array}$ & $\begin{array}{c}\text { 1 6億 } \\
\text { 円 }\end{array}$ & $\begin{array}{c}\begin{array}{c}6 \sim 10 \text { 億 } \\
\text { 円 }\end{array} \\
\end{array}$ & $\begin{array}{c}\text { 10億円 } \\
\text { 以上 }\end{array}$ & 計 \\
\hline \multirow[t]{2}{*}{ 土木 } & 0.493 & 0.803 & 0.908 & 0.939 & 0.952 & 0.718 \\
\hline & $4.9 \%$ & $8.1 \%$ & $11.8 \%$ & $10.7 \%$ & $6.2 \%$ & $7.7 \%$ \\
\hline \multirow{2}{*}{$\begin{array}{l}\text { とび・土エ } \\
\text { コンクリート }\end{array}$} & 0.335 & 0.626 & 0.781 & 0.841 & 0.894 & 0.573 \\
\hline & $1.7 \%$ & $1.5 \%$ & $3.3 \%$ & $6.2 \%$ & $2.2 \%$ & $2.6 \%$ \\
\hline \multirow[t]{2}{*}{ ほ装 } & 0.165 & 0.301 & 0.437 & 0.512 & 0.548 & 0.305 \\
\hline & $0.1 \%$ & $0.1 \%$ & $0.7 \%$ & $1.5 \%$ & $0.7 \%$ & $0.7 \%$ \\
\hline \multirow[t]{2}{*}{ 石 } & 0.186 & 0.311 & 0.393 & 0.512 & 0.423 & 0.296 \\
\hline & $0.0 \%$ & $0.0 \%$ & $0.2 \%$ & $0.1 \%$ & $0.2 \%$ & $0.2 \%$ \\
\hline \multirow[t]{2}{*}{ 水道 } & 0.149 & 0.228 & 0.306 & 0.402 & 0.442 & 0.234 \\
\hline & $0.0 \%$ & $0.1 \%$ & $0.2 \%$ & $0.0 \%$ & $0.1 \%$ & $0.1 \%$ \\
\hline \multirow[t]{2}{*}{ その他 } & 0.231 & 0.335 & 0.702 & 1.585 & 3.019 & 0.551 \\
\hline & $2.6 \%$ & $1.8 \%$ & $1.9 \%$ & $5.6 \%$ & $13.8 \%$ & $9.9 \%$ \\
\hline \multirow[t]{2}{*}{ 計 } & 1.559 & 2.604 & 3.525 & 4.793 & 6.279 & 2.678 \\
\hline & $9.4 \%$ & $11.7 \%$ & $18.0 \%$ & $24.1 \%$ & $23.3 \%$ & $21.3 \%$ \\
\hline
\end{tabular}

（造園工事業を除く，上段：建設業許可取得数／企業数，下段：工事高／全売上高）

また, 取得業種をみると土木一式工事業が最も多く, 売上高 1 億 円以上の企業においては $90 \%$ 以上の企業が取得し, 続いてとび・ 土工・コンクリート工事業, ほ装工事業, 石工事業, 水道工事業 となった。

アンケート調査結果から造園工事業以外の建設業への意向を示 したのが図ー11である。全体では, 現状維持としている企業が 84.7\%，拡大を図るとしている企業は $12.2 \%$, 逆に縮小を考えて いる企業は $3.1 \%$ となった。企業規模別にみると, 売上高 10 億 円未満の企業においては, 企業規模が大きくなるに従い拡大意向 の企業が増加し $25.0 \%$ までになるが, 売上高 10 億円以上の企業 では $18.8 \%$ と少なくなった。また，売上高 1 億円未満の企業では 拡大（5.0\%）よりも縮小（7.5\%）を考えている企業が多くなった。 企業の意向として最も多い現状維持の理由をまとめたのが表一 3 である。「必要な業種は既に取得している」,「本業に専念」等 の拡大を必要としない企業は $34.2 \%$ と最も多く, 続いて「公共 工事の減少」,「将来不安」で拡大の時でないとする企業は 17.1 $\%$, 「人材, 販路不足」等で「現状維持で限界」とする企業は $11.7 \%$ となった。また，拡大理由としては「造園工事が少ないの で他業種に事業拡大」, 「関連工事を行うため」が多く, 逆に縮小

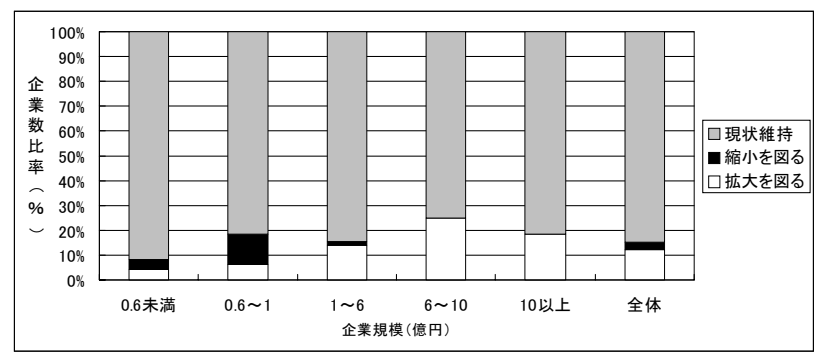

図－11＼cjkstart造園工事業以外の建設業への意向（アソケート調査）

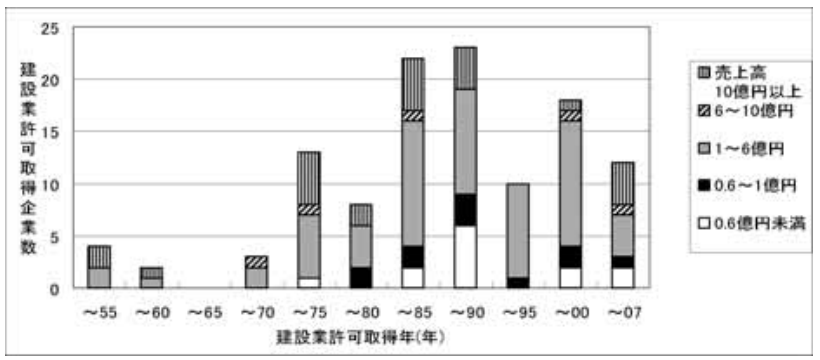

図－12 建設業許可取得時期（造園工事業を除く）（アソケート調査）
表 -3 建設業許可取得現状維持の理由（アソケート調查）

\begin{tabular}{|l|r|r|}
\hline \multicolumn{1}{|c|}{ 理由 } & \multicolumn{1}{c|}{ 企業数 } & 企業数比率 \\
\hline 現事業行うのに必要な業種は既に取得している & 29 & $26.1 \%$ \\
\hline 本業に専念 & 4 & $3.6 \%$ \\
\hline 業種拡大したばかり & 3 & $2.7 \%$ \\
\hline 事業良好 & 2 & $1.8 \%$ \\
\hline \hline 公共工事の減少(他業種への進出はできない) & 10 & $9.0 \%$ \\
\hline 将来展望が見えない & 9 & $8.1 \%$ \\
\hline \hline 現状維持で限界 & 8 & $7.2 \%$ \\
\hline 人材、技術不足 & 4 & $3.6 \%$ \\
\hline 販路がない & 1 & $0.9 \%$ \\
\hline \hline その他 & 7 & $6.3 \%$ \\
\hline \hline 無記入 & 34 & $30.6 \%$ \\
\hline & 111 & $100.0 \%$ \\
\hline
\end{tabular}

の理由は「公共工事の減少」「競争激化」となった。

造園工事業以外の建設業の許可取得は, 市場縮小に対して売上 高を維持するための他の建設業への進出であったかどうかを知る ために許可の取得時期をみたのが図－12 である。1950 年から 1985 年までを成長期, 1986 年から 1990 年をバブル期, 1991 年 から 2007 年をバブル経済崩壊後の市場の縮小期と区分すると, 成長期の建設業許可取得企業数は 52 社 $(54.2 \%)$ ，バブル期は 23 社 (24.0\%), 市場の縮小期は 40 社 (41.7\%) となった。市場縮 小に対する売上高維持のために建設業許可を取得したと考えられ る企業は全体の約 4 割あったと推察される。特に, 売上高 1 億円 以上 6 億円未満の企業に多く見られた。造園工事業以外の建設業 への意向と他建設業の許可取得時期を考え合わすと，バブル期の 事業拡大のために，また市場の縮小期の受注機会拡大のために既 に事業展開できる建設業許可を取得した状況となっていると考え られる。

(ii) 工事高と技術者数

(1)技術者数の全体像

建設業従業者を技術者を中心にして図－13 のとおり区分する ことができる。

経営事項審査データから図-13 の区分に従い, 従業者構成比 と 1 社当りの各従業者数を示したのが図-14である。全体では, 1 社当りの造園工事業技術者（他建設業の技術者を兼務している

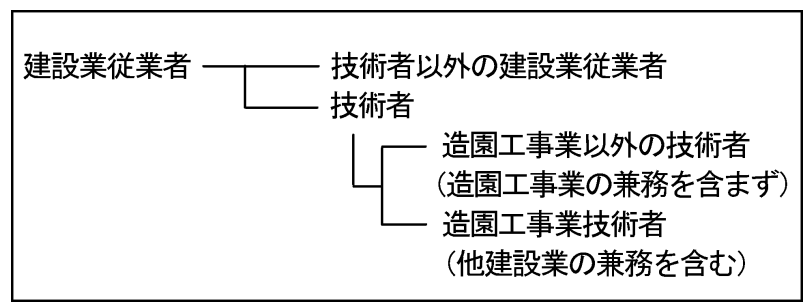

図ー13 技術者を中心とした建設業従業者の区分

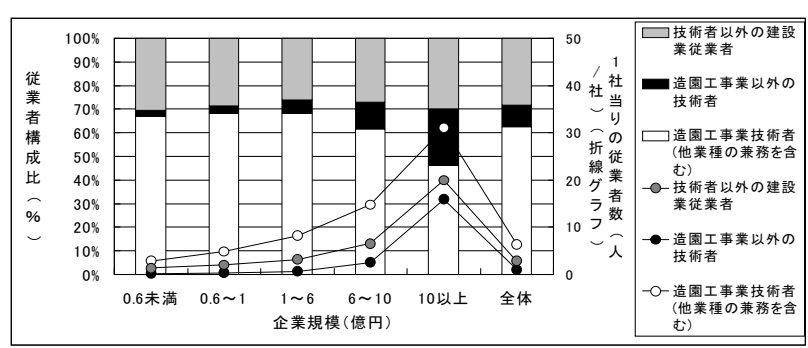

図-14建設業従業者数（経営事項審査" -夕） 
表 -4 建設業以外の事業内容（アソケート調査）（数字は企業数構成比）

\begin{tabular}{|c|c|c|c|c|c|c|}
\hline 企業規模 & $\begin{array}{c}\text { 6千万円 } \\
\text { 未満 }\end{array}$ & $\begin{array}{l}\text { 6千万円 } \\
\sim 1 \text { 億 } \mathrm{P} \\
\end{array}$ & $\begin{array}{l}1 \sim 6 \\
\text { 億开 } \\
\end{array}$ & $\begin{array}{l}6 \sim 10 \\
\text { 億 } \mathrm{H}\end{array}$ & $\begin{array}{c}\text { 10億円 } \\
\text { 以上 }\end{array}$ & 計 \\
\hline 公共の維持管理業務 & $88.2 \%$ & $81.3 \%$ & $88.7 \%$ & $100.0 \%$ & $93.8 \%$ & $88.6 \%$ \\
\hline 民間の維持管理業務 & $88.2 \%$ & $81.3 \%$ & $88.7 \%$ & $100.0 \%$ & $81.3 \%$ & $86.8 \%$ \\
\hline 指定管理者の委託 & $0.0 \%$ & $0.0 \%$ & $1.6 \%$ & $0.0 \%$ & $18.8 \%$ & $3.5 \%$ \\
\hline 樹木等の販売 & $5.9 \%$ & $6.3 \%$ & $12.9 \%$ & $0.0 \%$ & $31.3 \%$ & $13.2 \%$ \\
\hline 園芸資材の販売 & $5.9 \%$ & $6.3 \%$ & $16.1 \%$ & $0.0 \%$ & $25.0 \%$ & $14.0 \%$ \\
\hline 貸植木 & $0.0 \%$ & $0.0 \%$ & $4.8 \%$ & $0.0 \%$ & $18.8 \%$ & $5.3 \%$ \\
\hline 樹木の生産 & $0.0 \%$ & $0.0 \%$ & $3.2 \%$ & $0.0 \%$ & $0.0 \%$ & $1.8 \%$ \\
\hline 剪定枝等のリサイクル & $0.0 \%$ & $0.0 \%$ & $0.0 \%$ & $33.3 \%$ & $6.3 \%$ & $1.8 \%$ \\
\hline その他 & $5.9 \%$ & $18.8 \%$ & $16.1 \%$ & $66.7 \%$ & $56.3 \%$ & $21.9 \%$ \\
\hline 計 & $100.0 \%$ & $100.0 \%$ & $100.0 \%$ & $100.0 \%$ & $100.0 \%$ & $100.0 \%$ \\
\hline
\end{tabular}

技術者を含む）は 6.38 人 /社 $(62.4 \%)$, 造園工事業以外の技術 者（造園工事業の技術者を兼務していない技術者）は 0.98 人 $/$ 社 $(9.6 \%)$, 技術者以外の建設業従業者 2.87 人/社 (28.1\%) と なった。企業規模別にみると, 企業規模が大きくなるに従い造園 工事業の技術者, 造園工事業以外の技術者, 技術者以外の建設業 従業者は共に増加した。構成比でみると, 企業規模が大きくなる に従い造園工事業以外の技術者が他の従業者の増加の割合よりも 大きな割合で増加したことがわかる。しかし，この増加した造園 工事業以外の技術者の割合 (9.6\%) 以上に表-2 で示した造園 工事以外の工事高の割合 (21.3\%)) が大きい。この実態は技術 者の兼務とみることができる。

(2)技術者の兼務

造園工事業以外の建設業の技術者は造園工事業を兼務しない技 術者と造園工事業を兼務する技術者からなっている。例えば，図一 15 に示した売上高 10 億円以上の企業では 1 社当り実際に勤務し ている技術者（実技術者）は 47.0 人/社であったが, 各工事業 の技術者を全て加算した重複技術者数は 156.0 人/社となった。 1 人の技術者が 3.32 (156.0/47.0) 業種の技術者を兼務している ことになる。図一 15 の兼務率はこの数字を示している。また, 実技術者に占める造園工事業技術者の割合は全体で $86.7 \%$ 占 め, 売上高 6 億円未満の企業では $90 \%$ 以上, 6 億円以上 10 億円 未満の企業では $85.1 \% ， 10$ 億円以上の企業では $66.1 \%$ となって おり，造園工事業の技術者が他建設業の技術者を兼務しているも のと推察される。造園業企業が造園工事業以外の建設業に事業拡

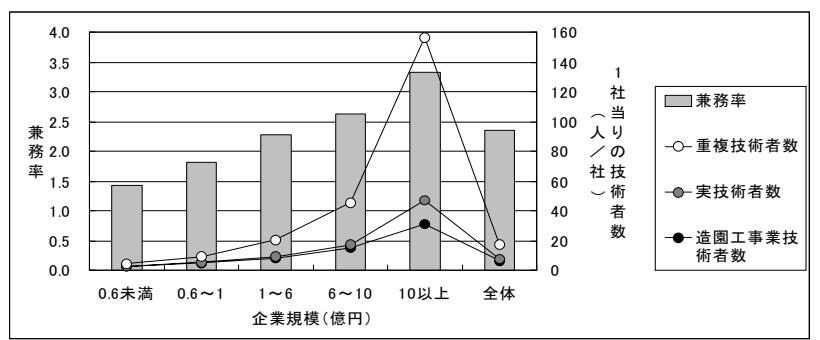

図-15 技術者の構成（経営事項審査デ" -タ）

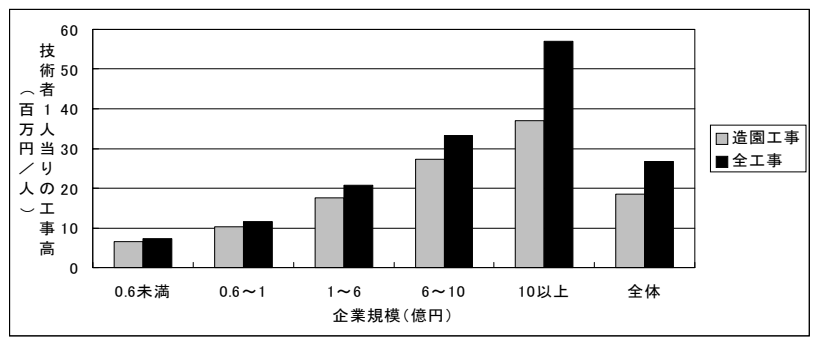

図-16 技術者 1 人当りの工事高（経営事項審査テ" -タ）
表 -5 事業拡大を図る事業内容（アソケート調査）

\begin{tabular}{|c|c|c|c|c|c|c|}
\hline 企業規模 & $\begin{array}{c}\text { 6千万円 } \\
\text { 未満 } \\
\end{array}$ & $\begin{array}{l}\text { 6千万円 } \\
\sim 1 \text { 億円 } \\
\end{array}$ & $\begin{array}{l}1 \sim 6 \\
\text { 億円 } \\
\end{array}$ & $\begin{array}{l}6 \sim 10 \\
\text { 億 } \mathrm{Y} \\
\end{array}$ & $\begin{array}{c}10 \text { 億円 } \\
\text { 以上 }\end{array}$ & 計 \\
\hline 公共の維持管理業務 & $6.7 \%$ & $15.4 \%$ & $16.4 \%$ & $33.3 \%$ & $20.0 \%$ & $15.8 \%$ \\
\hline 民間の維持管理業務 & $20.0 \%$ & $7.7 \%$ & $23.6 \%$ & $33.3 \%$ & $30.8 \%$ & $22.2 \%$ \\
\hline 指定管理者の委託 & --- & --- & $100.0 \%$ & --- & $100.0 \%$ & $100.0 \%$ \\
\hline 樹木等の販売 & $0.0 \%$ & $0.0 \%$ & $25.0 \%$ & --- & $40.0 \%$ & $26.7 \%$ \\
\hline 園芸資材の販売 & $0.0 \%$ & $0.0 \%$ & $20.0 \%$ & --- & $0.0 \%$ & $12.5 \%$ \\
\hline 貸植木 & --- & --- & $0.0 \%$ & --- & $33.3 \%$ & $16.7 \%$ \\
\hline 樹木の生産 & --- & -- & $0.0 \%$ & --- & --- & $0.0 \%$ \\
\hline 剪定枝のリサイクル & --- & --- & -- & $100.0 \%$ & $100.0 \%$ & $100.0 \%$ \\
\hline その他 & $0.0 \%$ & $0.0 \%$ & $70.0 \%$ & $0.0 \%$ & $22.2 \%$ & $36.0 \%$ \\
\hline 計 & $17.6 \%$ & $18.8 \%$ & $35.5 \%$ & $66.7 \%$ & $75.0 \%$ & $36.8 \%$ \\
\hline
\end{tabular}

大した時に造園工事業の技術者は造園工事の技術を基に他建設業 の知識と技術を習得し多能技術者となったと考えられる。技術者 が専門化，細分化するのではなく多能化したことが推察された。 (3)工事高と技術者数

図-16 は，技術者 1 人当りの工事高を示したものである。全 ての企業規模区分で造園工事業技術者 1 人当りの造園工事高より 屯全技術者（実技術者）1人当りの全工事高の方が高くなった。 造園技術者が他建設業の技術者を兼務することで技術者 1 人当り の工事高が高くなり，効率的な経営が図られたことになる。しか しながら，（i ）工事高の構成でみたとおり既に事業展開できる 建設業許可を取得した状況となっており，さらに他建設業に進出 することは難しい状況であると考えられる。

\section{(4) 建設工事以外の売上高}

アンケート調査から回答のあった 120 社の内（当該質問の無記 入は 16 社あった)，114 社，95.0\%の企業で建設工事以外の事業 が行われていた。この 114 社の建設業以外の事業内容を示したの が表一 4 である。

企業規模の大きさに関係なく $80 \%$ 以上の企業が「公共・民間 の維持管理業務」を行っており, 造園業にとって維持管理は重要 な事業であることがわかる。造園業は管理を通じて空間を作り上 げていくという他の建設業にない特性のためと考えられる。しか し, 維持管理業務以外に回答のあった事業は従来からの造園業の 関連事業であった。ただ「指定管理者の委託」,「剪定枝等のリサ イクル」は近年の新しい動向である。

建設業以外の事業への今後の意向を示したのが図 -17 である。 全体では事業を拡大しようとする企業は $36.8 \%$ (42 社), 縮小し ようとする企業は $1.8 \%$ (2 社)，現状維持としている企業は 42.1\%（48 社）となった。企業規模別にみると，企業規模が大 きくなるにつれて事業拡大の意向が見られた。

しかし，現在行われている各事業を今後とも拡大しょうとする 企業の割合をみると（表一 5 ), 各事業とも拡大しようとする企 業が少ないことがわかる。造園業にとって重要な維持管理業務に おいてすら公共の維持管理業務は $15.8 \%$, 民間の維持管理業務 は $22.2 \%$ の企業しか事業拡大の意向がない。維持管理業務は従

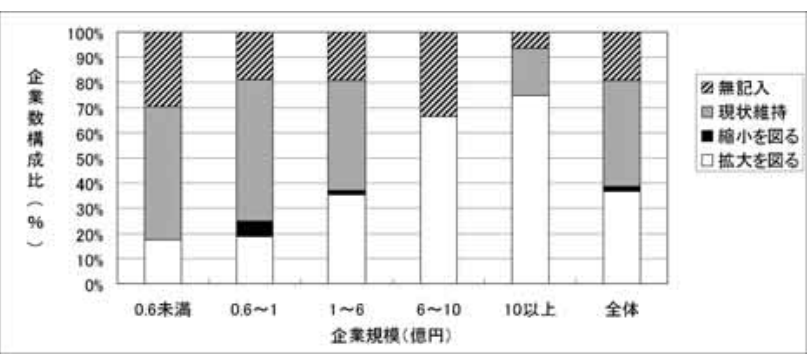

図-17 建設業以外の事業への意向（アソケート調査） 
表 -6 建設工事以外の事業拡大の理由（アソケート調査）

\begin{tabular}{|l|r|r|}
\hline \multicolumn{1}{|c|}{ 理由 } & 企業数 & 企業数比率 \\
\hline 需要が見込める & 8 & $19.0 \%$ \\
\hline 利益の安定確保が出来る & 5 & $11.9 \%$ \\
\hline 安定受注が見込める & 4 & $9.5 \%$ \\
\hline \hline 建設工事の伸びが見込めない & 9 & $21.4 \%$ \\
\hline 公共工事の減少 & 4 & $9.5 \%$ \\
\hline \hline 経験を活かせる & 2 & $4.8 \%$ \\
\hline 得意分野を活かせる & 2 & $4.8 \%$ \\
\hline 資産を活かす & 2 & $4.8 \%$ \\
\hline 関連業務である & 1 & $2.4 \%$ \\
\hline \hline その他 & 6 & $14.3 \%$ \\
\hline \hline 無記入 & 6 & $14.3 \%$ \\
\hline \multicolumn{1}{|c|}{ 計 } & 42 & $100.0 \%$ \\
\hline
\end{tabular}

来から実施している業務であり, 事業拡大を図る必要がないとの 判断だと考えられる。また, 維持管理業務以外の事業についても 従来からある造園業の関連事業であることから同様の判断がなさ れたと考えられる。ただ特筆すべきことは「指定管理者の委託」 と「剪定枝等のリサイクル」である。事業を実施している企業は, 「指定管理者の委託」が 4 社, 「剪定枝等のリサイクル」が 2 社と 少ないものの, 事業を実施している全ての企業が事業拡大の意向 を持っていた。新しい事業であり, 時代の要求に合致した事業と 考えられる。

事業拡大の理由をみたのが表一 6 である。「需要が見込める」,

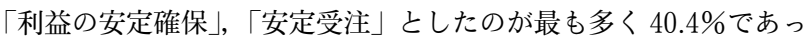
た。続いて，「建設工事の伸びが見込めない」，「公共工事の減少」 のために建設工事以外の事業拡大を考えている企業が $30.9 \%$, 「経験」「資産」等が活かせるとしたのが $21.6 \%$ となった。市場 の縮小時代においては, 需要が見込めることが前提となるが, 安 定した受注, 利益の確保ができ, そして新たな投資を必要としな い現有する資産や経験を活かせることが企業が望む事業要件と考 えられる。「指定管理者の委託」,「剪定枝等のリサイクル」は, これらの要件をほぼ満たしている事業となっている。

また, 新規事業の計画があるかどうかを尋ねたところ, 136 社 中, 計画があると答えた企業が 31 社, $22.8 \%$ あった。厳しい市 場環境に取り組もうとする企業姿勢を示すものであり, 市場の縮 小を糧に新たな発展の萌芽を感じるものである。

\section{4. おわりに}

\section{（1）まとめと課題}

バブル経済崩壊後, 造園業市場の縮小に対応した造園業の実態 を売上高を通してみてきた。その実態は, 本研究の調查対象とし た造園業企業全体の売上高の約 $2 / 3$ 以上が造園工事以外の建設 工事拉よび建設工事以外の事業から確保されていた。造園工事に おいては, 工事高の $70 \%$ 以上が民間工事で確保されていた。公 共工事の大きな比重を占めると考えられる都市公園関係事業費の 新設費, 改良費は 1993 年度の 6,283 億円をピークに 2003 年度に

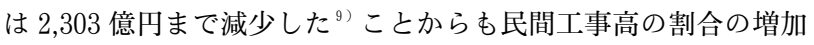
は当然の結果と考えられる。また, 売上高の $2 / 3$ 以上を占める 造園工事以外の建設工事抒よび建設工事以外の事業についての今 後の意向は，造園工事以外の建設工事については事業拡大を図る としている企業は $12.2 \%$ しかなく, 建設業以外の事業について は $36.8 \%$ の企業が事業拡大を考えていた。しかし, 建設工事以 外の個々の事業についての拡大意向は $20 \%$ 前後にとどまった。 ただ，「指定管理者の委託」，「剪定枝等のリサイクル」といった 新たな事業を行っている全ての企業は今後も事業拡大の意向をもっ
ていた。さらに，22.2\%の企業が新たな事業計画があるとしてい た。以上の結果から，造園業企業は公共工事から民間工事へ，ま た造園工事からその他の事業へと市場の縮小に対応した企業行動 をとっており，その行動は企業の存続のための売上高確保の行動 であったと考えられる。

景気の変化に伴う造園業市場の変化を造園業が左右することは できないが，造園業企業が独自性を発揮し，自らが売上高を確保 するための新たな事業展開をどのようにして行っていくかが造園 業の課題と考えられる。既に, 新たな事業展開を自らが行う時代 と考えている企業が $20 \%$ 以上いると考えられる。また「指定管 理者の委託」,「剪定枝等のリサイクル」のような新たな事業の取 り組みも見られた。さらに, 新たな事業展開の可能性を次のとお り見出すことができる。

\section{(2) 提言}

業種別電話張（タウンページ）から日本の造園業の営業所（支 店を含む）は, 約 27,000 箇所あることが確認された。その中で, 東京都, 愛知県, 大阪府といった大都市圈を中心に個人庭園の維 持管理等の事業を展開しているベンチャー企業があった（仮に(粖) $\mathrm{O}$ 社とする)。(侏) $\mathrm{O}$ 社の業務内容は別として, 個人庭園の中に新 たな事業を見出した事例と見なすことができる。造園業が有して いる技術に個人庭園管理のための新たなサービス, システムの構 築ができれば新たな事業展開の可能性があると考えられる。

また, 進士は造園業が志向する方向として「オルターナティブ・ テクノロジー」を示している ${ }^{3)}$ 。経済学においても，これまでの 経済成長を支えてきた工業化は原料 $\rightarrow$ 生産 $\rightarrow$ 消費 $\rightarrow$ 廃棄といった 一過性の流れを特徵とし, 生態系に組み込まれるものでなく, 永 続性を欠くものであるとし，「経済成長と環境・資源との調和に 配慮した平衡経済論」が提唱されている ${ }^{10)}$ 。造園業は平衡経済論 の考えに合致した産業として，造園業が扱う植物材料と現有の技 術に自然再生技術を加えることで工業化により破壊された自然の 生態系を修復する新たな事業展開の可能性を見出すことができる と考えられる。

\section{補注・引用文献}

1) 国土交通省総合政策局情報管理部情報安全・調查課監修 （1991 2006）：建設工事施工統計調查報告：(財建設物価調查会

2 ）田中史郎 - 中村攻・齊藤雪彦・藤井英二郎・鳥井幸恵 - 近江屋一朗 （2007）：統計資料からみた造園工事業の企業数, 完成工事高, 従業 者数, 付加価値額の推移に関する考察 : ランドスケープ研究 71(5), 487-492

3 ）進士五十八（1994）：造園産業論の構築に向けて：ランドスケープ研 究 58(2), 115-118

4 ）建設業法第 27 条の 23 で「公共性のある施設又は工作物に関する建設 工事で政令で定めるものを発注者から直接請け負扔うとする建設業者 は，国土交通省令で定めるところにより，その経営に関する客観的事 項について審查を受けなければならない。」としており，この審查を 経営事項審查と言う。本研究では公表されている評価結果デー夕を用 いた。

5 ）(社)日本造園建設業協会は主に公共工事を行う造園業企業の日本最大の 組織である。

6 ）(社)日本造園組合連合会は主に民間工事を行う造園業企業の日本最大の 組織である。

7 ）建設業法第 3 条第 1 項（建設業の許可）より，建設業を営もうとする 者は，都道府県知事または国土交通大臣の許可を受けなければならな いとしている。ただし，政令で定める 5 百万円未満の建設工事のみを 請け負う者は，建設業許可を取得しなくてもよいことになっている。

8 ）(社)日本造園建設業協会技術調查部長 野村徹郎, (社)日本造園組合連合 会理事・事務局長 井上花子の両氏にヒアリングを行った。

9 ）社日本公園緑地協会（2005）：公園緑地マニュアル，134-135

10）清成忠男（2000）：中小企業読本：東洋経済新報社，40-41 